happily, a complete absence of unimportant or rare diseases and apart from reference to diathermy coagulation of the tonsils, controversial matters are wisely avoided. In particular, the section on diseases of the ear evokes admiration for its clarity.

Whilst appreciating the good qualities for which this book is well known, the reviewer feels justified in referring to what appear to him to be some adverse points. In the section on antibiotics, although 'side effects' are listed, a-granulocytosis due to chloromycetin, and fatal enteritis due to 'drug resistant' organisms, are not mentioned. Experience, and the literature in recent years suggest that these, the greatest dangers of antibiotic treatment, cannot be too widely known. The dramatic cure of laryngeal tuberculosis by streptomycin has not found its place in this edition, although cautery and diathermy of the larynx are still described. In the treatment of a-granulo-cytosis the prophylactic use of systemic penicillin is of proven value, and deserves description.

In the discussion of reactionary haemorrhage after tonsillectomy, attempts to seize and ligate bleeding points in the conscious patient are advocated. Whilst this might be achieved by great dexterity on an exceptionally co-operative patient, it should be emphasized (and the author does not mention this) that the surest and safest way to deal with a potentially dangerous reactionary haemorrhage is to give a second anaesthetic and ligate accurately under optimum conditions. Various authorities have testified to this. With an experienced anaesthetist the dangers of inhalation are far less than those of delay and failure in arresting the bleeding.

With regard to pre-operative preparation for tonsillectomy the giving of fluids by mouth, up to two hours before operation, seems unsafe, and is not consistent with the author's sound advice in a later section that the patient should come to the table in a fasting condition.

One last point concerns the advice that a fractured nose may be straightened under a simple pentothal anaesthetic. This again, would seem unwise, unless precautions are taken to prevent inhalation of blood and laryngeal spasm which can be expected from the profuse bleeding which often occurs during the manoeuvre.

It is a matter for regret that such faults should mar what is in all other respects acknowledged to be a valuable text book.

H.J.G.

\section{CIBA FOUNDATION COLLOQUIA ON ENDOCRINOLOGY}

Volume IX-Internal Secretions of the Pancreas

Edited by G. E. W. Wolstenholme, O.B.E., M.A., M.B., B.Chir., and Cecilia M. O'Connor, B.Sc. Pp. xii +292 , with 100 illustrations. Lóndon: J. \& A. Churchill Ltd. I956. 40s.

Carbohydrate metabolism possibly is distinguished from other branches of physiology and medicine in that it has had a longer innings than perhaps any other and that it shows no signs of being ' out ' in the near future. In fact, boundaries are being hit by the younger members of the carbohydrate team as often as the older members hit them between 1922 and 1945 . Each new finding is of practical importance in the interpretation, diagnosis and treatment of the disorders of the body in which sugar disturbances appear.

This Colloquium differs from its predecessor in this field in 1952 in that the clinical aspects are emphasized less than the basic fundamental sciences; these are called in to explain the phenomena. The members of this Colloquium (selected with the usual care that has come to be associated with the Ciba Foundation Colloquia) comprised both senior and younger workers. They were, however, a mixture of physicists, chemists and biologists.

This monograph summarizes the active growing points at the present day. The $\alpha$-cells in the pancreas comprise about 20 per cent. of the islet cells. The $\beta$-cells secrete insulin, whereas the $\alpha$-cells secrete glucagon. The glucagon is hyperglycaemic in action in contrast with insulin: it acts on the phosphorylase system in the liver: it inhibits insulin action in vitro and it stimulates growth in the chick embryo. In addition much attention is being given to cell permeability to sugars. It rarely, if ever, appears that sugars enter cells, whether muscle, erythrocytes or brain by mere diffusion. It is almost entirely an active intervention of or by their cell membrane and one which is different with different membranes. With muscle only is it stimulated by insulin so that sugar uptake is promoted.

Finally, there is a fascinating group of papers on the physical and chemical structure of insulin by Professors Eugène Fredericq, David Waugh and Doctors Sanger and Dorothy Hodgkin of Cambridge.

\section{A.St.G.H.}

\section{THE DIAGNOSIS AND TREATMENT OF POSTURAL DEFECTS}

By Winthrop Morgan Phelps, M.D., R. J. M. Kiphuth, M.P.E., and Charles WeER GoFf, M.D. Second Edition. Pp. xi + 190, with 87 illustrations. Oxford: Blackwell Scientific Publications Ltd. 1956. 47s. 6d.

In this work the development of man's erect posture is quickly traced from the early quadrupeds. Varieties of ' normal' posture have been arrived at following study of great numbers of men in the American armed forces in World War II.

The development of the normal child and the defects which may appear are described and the diagnosis of defects in adults is fully described.

Finally, corrective exercises are explained and illustrated.

The material is well set out and illustrated, and the whole work is of great use to all who have to deal with physical education and the correction of faults of posture. 